\title{
Evaluation of Disaster Preparedness Earthquake Policies in Padang City
}

\author{
Indry $^{1}$, Alfan Miko $^{2}$, Roni Ekha Putera ${ }^{3}$ \\ \{ Indry.map@gmail.com ${ }^{1}$, alfanmiko@ hotmail.com², \\ roniekhaputera@soc.unand.ac.id $\left.{ }^{3}\right\}$ \\ Departement of Public Administration, Faculty of Social and Political Science, Universitas Andalas, \\ Padang, Indonesia ${ }^{1,3}$, Departement of Sociology Sciences, Faculty of Social and Political Science, \\ Universitas Andalas, Padang, Indonesia ${ }^{2}$
}

\begin{abstract}
Disaster preparedness means planning action to respond in case of disaster. This activity is important as a form of disaster risk reduction. Padang city is one of the areas that have high earthquake vulnerability index. So, disaster preparedness becomes an important thing to do. BPBD as a leading sector in disaster has undertaken various programs and activities of disaster preparedness. This research uses qualitative method with descriptive approach. With primary and secondary data collection methods. The results of the study found that programs and preparedness activities undertaken by BPBD are still not effective. This can be seen from the maintenance of signs and evacuation baliho not yet good and there are still people who are in the red zone tsunami is not well aware of the steps of early rescue in the event of a disaster. This study concluded that BPBD Kota Padang should make improvements in disseminating disaster preparedness more effectively so that the objectives of disaster management policy can be achieved appropriately and evenly.
\end{abstract}

Keywords: Please list your keywords in this section.

\section{Introduction}

The city of Padang is in a zone along the line of a $6,500 \mathrm{~km}$ subduction zone earth to the west of Sumatra Island. The collision of the Indian Ocean Plate and the Australian Plate that infiltrated beneath the Eurasian Plate form the Benioff Zone, which actively continues to move east-west which is a zone of seismicity with high enough seismicity ${ }^{1}$. Geographically the city of Padang is located in the coastal area of the island of Sumatra, with a distance of $84 \mathrm{~km}$. The people of Padang mostly live in coastal areas. Based on the data of Community Alert Tsunami Padang that mention there are about 400,000 residents who occupy the coastal areas still do not have a good ability to respond in case of earthquake disaster ${ }^{2}$.

The earthquake experience that occurred in the city of Padang in September 2009 of magnitude 7.9 SR caused severe damage and killed many lives, 383 people died, 431 people were seriously injured and 771 people were slightly injured. Meanwhile, physical damage was recorded 33,597 heavily damaged buildings, 35,819 units were damaged and 37,615 units were

\footnotetext{
${ }^{1}$ https://en.wikipedia.org/wiki/Geography_Kota_Padang. accessed on May 28, 2018. At: 21:50. ${ }^{2}$ Data KOGAMI Kota Padang, http://www.gitews.org/tsunami-kit/en/E5/info/KOGAMI.pdf. accessed on June 7, 2018
} 
lightly damaged ${ }^{3}$. This incident brought a fairly high traumatic for the people of Padang City. The great number of victims is considered as the result from the lack of preparation to face disasters, especially earthquake, particularly one, potential for tsunami ${ }^{4}$. The lack of knowledge and capacity of the community on disaster preparedness makes panic and confusion take the right steps when disaster strikes.

It takes effort by the Padang City Government to provide improved capacity and good knowledge of disaster preparedness for the community. Hyogo Declaration 2005-2015 on the importance of increasing preparedness at all levels of disaster risk reduction, including community preparedness. Providing disaster preparedness training to the community is considered an action taken to empower ordinary citizens to help themselves, their families, their neighbors, or complete strangers ${ }^{5}$. So by providing special training to the community this is expected to minimize the risk of disaster. Unfortunately, disaster preparedness education and training is not as easy as just telling people what they should do. This process, which includes public awareness, education, and outreach, is one involved relying on many years of practice and many different disciplines ${ }^{6}$. So to be able to achieve these goals required continuous and continuous activities to the community in the disaster area.

However, the readiness of the people of Padang City, especially in terms of disaster preparedness is still not maximized. There are still many people who do not have basic knowledge about disaster preparedness. This we can know from the earthquake experience in 2009, the people of Padang City when it was scattered out of the house to save themselves and also there is a severe congestion that caused the accident. The absence of a Disaster Evacuation Map Map at that time resulted in people not knowing the safe routes for them to save themselves. The people of Padang City then experienced a severe panic because it was added to the tsunami issue, so people ran to a place that they considered safe to save themselves. This is due to the lack of capacity and knowledge of the community about their disaster preparedness.

The low level of simulated activities and activities gained by the community at the time, made them panic when disaster struck. Disaster prevention activities and activities are still minimal conducted by the Padang City Government. The low awareness of the Government against disaster management makes them think that disaster is something unexpected, unplanned and act of $\mathrm{God}^{7}$. Whereas the government should be more responsive to the condition of Padang City which has high disaster vulnerability.

The issuance of Law Number 24 Year 2007 on Disaster Management and Government Regulation of Padang City Number 3 Year 2008 on Disaster Management should have a positive impact on capacity building and earthquake disaster preparedness. This is because the regulation has been regulated about disaster prevention activities and programs especially earthquake preparedness. So the public should already know the responsive action in a good self-sustaining effort when disaster strikes and knows the safe evacuation area. Based on these issues, this article would like to evaluate the Earthquake Disaster Preparedness Policy in Padang City.

\footnotetext{
${ }^{3}$ Data BPBD Padang. Presentation Materials Seminar Year 2018

4 Putera, Roni Ekha; Heru Nurasa dan Yogi Suprayogi Sugandi. (2016). Synergizing Stakeholders in Reducing Risk of Earthquake and Tsunami-Disaster in the Most Vulnerable Area. International Journal of Administrative Science \& Organization, Vol 23 Number 3.

${ }^{5}$ Damon P. Coppola. (2006). Introduction to International Disaster Management

${ }^{6}$ Coppola, Damon P.Maloney, Erin K. (2017). Communicating Emergency Preparedness Practical Strategies for the Public and Private Sectors, Second Edition-CRC Press.

${ }^{7}$ Kusumasari, Bevaola. Disaster Management and Local Government Capacity. Yogyakarta: Gavamedia. It: 64
} 
This research uses qualitative method with descriptive approach. Using two primary and secondary data collection sources. Primary data is data obtained from interview respondents from through the results of observations of researchers in the field related to the implementation of disaster preparedness policy in the city of padang. Meanwhile, secondary data is generated from written documents, literature studies of legislation. Such as Padang City Regional Regulation about disaster preparedness.

While the technique of data analysis using qualitative data analysis techniques. Broadly speaking, Miles and Huberman share data analysis in three stages, namely data codification, data presentation and conclusion or verification ${ }^{8}$.

\section{Evaluation of Public Policy}

Evaluation of the policy is done to know the implementation of a policy whether it has gone well or not. In other words, the policy evaluation wants to see the effectiveness of the implementation of a policy. In general, policy evaluations can be said to be activities that involve estimating or assessing policies that include the substance, implementation and impact of the implementation of the policy (Anderson in Winarno, 2008: 166). According to Harris (2010) citing Rossi et al (2004) that evaluation is the use of testing methods or social research to determine the effectiveness of a program. Meanwhile, according to Tuckman (1985) cited by Sopha Julia (2010), evaluation is a process to know or test whether an activity, process activities, output a program has been in accordance with the purpose or activity that has been determined. A program is not only designed and implemented but also measured to the extent of its effectiveness and efficiency. In a shorter language evaluation is an activity that aims to assess the "benefits" of a policy (Winarno, 2012).

When policy results in fact have value, this is because they contribute to a goal or goal. In this case, it can be said that the policy or program has reached a meaningful level of performance, which means that the policy issues are made clear or resolved ${ }^{9}$. However, if a policy can not achieve the objectives and objectives that have been compiled before, then a policy evaluation is important to do to assess the failure of the policy.

The evaluation of the policy would be to identify four aspects, namely: (1) the policymaking process, (2) the implementation process, (3) the policy consequences and (4) the effectiveness of the policy impact ${ }^{10}$.

In this study, researchers use the theory put forward by William N Dunn, because researchers want to know the achievement of disaster preparedness policy in the city of Padang. How these Disaster Preparedness Policies can have a positive impact on the community to provide them with increased capacity and knowledge of disaster preparedness.

To facilitate evaluation activities, Dunn evaluates that using the six decision criteria to solve policy problems include ${ }^{11}$ :

\footnotetext{
${ }^{8}$ Afrizal, 2014. Qualitative Research Methods (an attempt to support the use of qualitative research in various disciplines). Jakarta: PT RajaGrafindo Persada. It: 178.

${ }^{9}$ Abdul Wahab, Solichin. Evaluation of Public Policy. 1994. Jakarta: PT RajaGrafindo

Persada. Pages: 9.

${ }^{10}$ N. Dunn, William. Introduction to Public Policy Analysis. 2003. Yogyakarta: Gadjah Mada

University Press. Hal: 608.

${ }^{11}$ Nugroho, Dr. Riant, 2017. Public Policy. Jakarta: PT Elex Media Komputindo. Hal: 324.
} 


\begin{tabular}{ll}
\hline Question & Criteria Type \\
\hline Effectiveness & Is the desired result achieved? \\
Efficiency & How many resources are used? \\
Adequacy & How far the achievement of the desired result has solved the problem? \\
Equity & Are costs and benefits equitably distributed to different target groups? \\
Responsiveness & Does the policy outcome satisfy the needs, preferences, or values of \\
& particular groups? \\
Accuracy & Is the desired result really useful or valuable? \\
\hline
\end{tabular}

\section{Disaster Management Policy}

Disaster Management Policy as stipulated in Law Number 24 Year 2007 and Local Government Regulation of Padang City Number 3 Year 2008 explains that the implementation of disaster management is a series of efforts covering the determination of development policies that are at risk of disaster, disaster prevention activities, emergency response and rehabilitation. Implementation of disaster management is the responsibility and authority of the local government, so this activity must be well planned and coordinated so that the purpose of the implementation can be achieved well.

The implementation of disaster management consists of three phases that include predisaster activities, emergency response and rehabilitation. Preparation of disaster management planning is determined by Local Government and coordinate with Regional Disaster Management Agency (BPBD).

Current disaster management activities have undergone a shift shift, ie disaster management no longer emphasizes the emergency response aspect but rather more specifically on disaster preparedness through capacity building through planning, training and training.

Preparedness means planning action to respond in case of disaster. Preparedness can also be defined as a state of standby in the face of crises, disasters or other emergencies. Godschalk (1991: 134) emphasizes preparedness as an action taken before an emergency to develop operational capabilities and to facilitate effective responses if an emergency occurs ${ }^{12}$. This means that disaster preparedness is a preventive measure that ensures that communities will have preparedness in the face of disasters and are able to respond effectively before a disaster occurs $^{13}$. Padang City Government should now be able to realize the culture of disaster preparedness to the community, so that people can act and respond to disaster well. This is why this determines the safety of people in the face of disaster (ISDR / UNESCO, 2006) ${ }^{14}$. Predisaster preparedness behaviors try to inform the public about the types of actions they can take before the disaster occurs, while not always reducing the likelihood of an event occurring, allowing them to better manage the consequences they face ${ }^{15}$.

Experts mention several important reasons that make disaster preparedness an important component of overall disaster management (Auf der Heide, 1989; Dyne, 1994; Kreps, 1992; Mileti 1991:

12 Bevaola. Disaster Management and Local Government Capacity. Yogyakarta: Gavamedia. Page: 24.

${ }^{13}$ Ibid, hal: 25

${ }^{14}$ UNISDR, 2012 How To Make Cities More Resilient: A Handbook For Local Government Leaders.

15 Damon Coppola, Erin K. Maloney-Communicating Emergency Preparedness_ Strategies for Creating a Disaster Resilient Public (2009). Hal: 18 
1. Effective response and preparedness activities can help save lives, reduce injuries and limit property damage and minimize any kind of disruption that can be caused by a disaster,

2. Preparedness helps protect community values and reduce unwanted conditions during a disaster,

3. Preparedness improves coordination and communication among organizations and establishes responsibilities for key players, such as public officials, state officials, local officials, and hospitals,

4. Preparedness helps identify resources (personnel, time, finances, equipment, equipment or facilities) that the community may need for response and recovery action steps,

5. Preparedness identifies some important functions that need to be done in times of disaster, such as resource management, evacuation and damage assessment.

\section{Evaluation of Policy Policy Earthquake Disaster Preparation in Padang City}

To find out the results of the evaluation of the earthquake disaster preparedness policy in padang city, William N. Dunn's theory states that there are six criteria in knowing the decision criteria for solving policy problems such as effectiveness, efficiency, adequacy, equity, responsiveness and accuracy.

\subsection{Effectiveness}

According Winarno (2002: 184): Effectiveness comes from the word effective that contains the sense of achieving success in achieving the goals set. Effectiveness is also called usage. Effectiveness is always related to the relationship between expected results and actual results achieved.

BPBD Kota Padang as the implementor of this policy conduct some activities and programs related to disaster preparedness in Padang City. The preventive activity of disaster mitigation will also engage the young communities in Padang City, in order that all walks of life can be synergy to one each other in improving alertness towards disaster ${ }^{16}$.

Field Prevention and preparedness BPBD Padang City provides training to Disaster Preparedness Groups (KSB) in the whole kelurahan in turn. The purpose of this activity is to increase capacity and give greater role to members of Disaster Preparedness Group or KSB, which is in 104 sub-districts in 11 sub-districts in Padang city. The material given to disaster volunteers is about disaster mitigation or disaster preparedness.

However, this activity is not carried out continuously due to the limited budget allocated in the Regional Revenue and Expenditure Budget (APBD), this makes the goal of the activity has not been achieved effectively. Ideally in providing a knowledge of preparedness is done continuously, because if not then the community will not be able to apply it right when disaster strikes. Evidently, until now people are still experiencing panic and do not apply the knowledge they get during the simulation. In 2006 LIPI and UNESCO conducted a survey on the level of

\footnotetext{
${ }^{16}$ Putera, Roni Ekha dan Suherlan. (2015). When The Disaster Treatment In The Head Of Eyes: The Efforts Of Mitigation Policy And Reduction Of The Disaster Risk In Padang City. International Refereed Research Journal Vol.-VI, Issue - 4(1).
} 
community preparedness to face the earthquake and tsunami in Padang and Bengkulu. The preparedness parameters used are five that are disaster knowledge, disaster preparedness policy, emergency response plan, early warning, and resource mobilization. The result is a low level of public preparedness (http://www.rmol.co).

\subsection{Efficiency}

According Winarno (2002: 185) efficiency (efficiency) with regard to the amount of effort required to produce a certain level of effectiveness. Efficiency which is a synonym of economic rationality, is a relationship between effectiveness and effort, the latter generally measured from the monetary cost. Efficiency is usually determined through the cost per product or service unit calculation. Policies that achieve the highest effectiveness at the smallest cost are called efficient.

Implementation of disaster preparedness activities and programs is considered inefficient, due to the fact that the budget available for community preparedness activities in Padang City disaster risk reduction efforts is very small. Whereas the government should provide a large budget to implement this program, considering that the reality of Padang City has great potential for disasters, as mentioned by BNBP in 2013, namely Padang City is ranked 10th National and the first rank of the existing district in West Sumatra . Improving the capacity of preparedness should be the focus of government in realizing the disaster preparedness culture, but this activity can not run continuously due to the limited budget of the government to make this happen.

Village Disaster Awareness (KSB) formed by BPBD Padang in the end can not run properly due to limited budget available. Because in running the program of course the government must provide a regular budget for socialization activities to the community. The provision of billboards of red zone maps and evacuation routes in pairs at several points in Padang City would require a large budget, not just installation but also regular maintenance costs. As said by the Chairman of BPBD Padang City, that many of the current signs are damaged and must be repaired and replaced. But this is constrained cost and budget.

\subsection{Adequacy}

According to Winarno (2002: 186) Adequacy in public policy can be said that the goals achieved have been felt sufficient in many ways. Adequacy relates to how far a level of effectiveness satisfies a need, value, or opportunity that fosters a problem. Adequacy is still related to effectiveness by measuring or predicting how far the alternatives can satisfy the need, value or opportunity in solving the problem.

In providing socialization to the community about disaster preparedness knowledge BPBD Kota Padang has conducted socialization and simulation in various schools, hospitals, offices. Installation of signs and evacuation baliho has also been done at some point in the city center. Shelter and potential shelter development has also been done, but the problem is the availability of shelter has not been able to accommodate all the people of Padang City in the red zone. Information about potential shelters that can be used as a gathering point for the community when there is a tsunami threat is also not well socialized. This is marked by the still many people who do not know where the existence of existing shelter in the city of Padang. So this kind of information should be further enhanced by BPBD Kota Padang to the community, so that people understand and can act quickly when there is a possibility of tsunami hazard.

\subsection{Description}

According to Winarno (2002: 187) Flattening in public policy can be said to have meaning with justice given and obtained the target public policy. The criteria of equity are closely related 
to legal and social rationality and refer to the distribution of effects and effort between different groups in society. A policy of oriented smoothing is a policy whose outcome or business is fairly distributed.

The result of LIPI (2006) study found that the Padang community preparedness level is only 56\% and BNPB survey conducted in 2013 about knowledge index and community preparedness of Padang City, depicting from 10 villages surveyed only 2 villages in medium category, The remaining 8 are in the low category ${ }^{17}$. This fact shows that still not well socialized knowledge about preparedness to society of Padang city evenly. Padang City Government together with BPBD Kota Padang should work harder to build full awareness about the importance of knowledge about this disaster. Because if the knowledge of disaster preparedness can not be well understood by the community, this certainly can not have a positive impact on the objective of the implementation of disaster preparedness program in Padang City. And also can threaten the safety of the community against the threat of earthquake and tsunami disaster that may occur.

\subsection{Responsivity}

According Winarno (2002: 189) Responsiveness in public policy can be interpreted as a response of an activity. Which means the response of public policy goals to the implementation of a policy. Responsiveness with regard to how far the policy can satisfy the needs, preferences, or values of certain community groups. The success of the policy can be seen through the response of the community responding to the implementation after first predicting the impact that will occur if the policy will be implemented, as well as the community response after the policy impact has begun to be felt in the form of support / rejection.

The community's response to the socialization and disaster preparedness program is still lacking. The results of observations of researchers on some activities that have been done by BPBD that enthusiastic community against disaster activities is still low. This is marked by disaster exhibition activities conducted by BPBD Padang some time ago is considered empty of visitors. Promotion related to the existence of this activity has been done well in various social media, but few days of the exhibition held by people who come to the exhibition disaster very few in number. This fact is unfortunate, because the people should be more active in searching for information on disaster preparedness. People still think that disaster is the destiny and the will of God, so the attitude of resignation to the possibility of disaster happening is still understood by society. High socialization is needed so that public awareness of disaster preparedness can be improved, so that the objectives of disaster risk reduction can be achieved well.

Some simulation activities that have been done by BPBD Padang also considered not able to give good response. This can be seen during the simulation in the framework of the National Disaster Preparedness Day ago, the community is still relaxed and does not seem serious in doing the simulation activities. Whereas simulated activities should be a good opportunity to test the extent of disaster preparedness knowledge for them in responding if a disaster is actually going to happen.

\subsection{Precision}

17 TIM LIPI, 2006, Community Preparedness Study in Anticipating Earthquake and Tsunami Disaster in Indonesia, LIPI-UNESCO / ISDR, Jakarta. www.buku-e.lipi.go.id/utama.cgi?lihatarsip\&jans001...1. Retrieved on June 28, 2018.path 00.14 
According Winarno (2002: 184) Accuracy refers to the value or price of the program objectives and on the strong assumptions underlying those goals. The criteria used to select a number of alternatives for recommendation by assessing whether the results of the recommended alternatives are a viable objective option. The eligibility criterion is associated with substantive rationality, since this criterion concerns the substance of purpose rather than the means or instrument for realizing that goal.

If reviewing the objectives of disaster preparedness for the community is to provide disaster knowledge so that communities can respond effectively when disasters occur. Padang City Government, in this case BPBD Padang as implementor has done various programs and activities well. However, when viewed from the achievement of the results of the goal is still not maximized. The level of community preparedness assessed so far is still low. Public awareness of the importance of knowledge of disaster preparedness is also considered low, as evidenced by the existence of some activities undertaken by BPBD, public participation is still low.

\section{Conclusion}

Disaster Preparedness Policy The earthquake disaster in Padang City has been done well, but in its implementation it needs to be dilakuakn with sustainable. Because, in providing disaster knowledge required routine activities and kotinue so that people can absorb knowledge and apply it well when disaster happens. It takes the politic will of the government in implementing this policy, by providing adequate budget for the implementation of disaster preparedness policy can be done optimally, so that all people of Padang City get good knowledge of preparedness equally in all area of Padang City.

To provide disaster preparedness knowledge on an ongoing basis, the Padang City Government can incorporate disaster curriculum into subjects as well as extracurricular activities in schools. With the disaster curriculum in schools, the knowledge of disaster preparedness can run continuously and can provide understanding as early as possible for the community. So in the end people will be able to apply it well when disaster occurs.

\section{References}

[1] Abdul Wahab, Solichin. Evaluation of Public Policy. 1994. Jakarta: PT RajaGrafindo Persada.

[2] Afrizal, 2014. Qualitative Research Methods (an attempt to support the use of qualitative research in various disciplines). Jakarta: PT RajaGrafindo Persada.

[3] Bevaola. Disaster Management and Local Government Capacity. Yogyakarta: Gavamedia.

[4] Coppola, Damon P. Maloney, Erin K. (2017). Communicating Emergency Preparedness Practical Strategies for the Public and Private Sectors, Second Edition-CRC Press.

[5] Damon P. Coppola. (2006). Introduction to International Disaster Management.

[6] Damon Coppola, Erin K. Maloney-Communicating Emergency Preparedness_ Strategies for Creating a Disaster Resilient Public (2009).

[7] Kusumasari, Bevaola. Disaster Management and Local Government Capacity. Yogyakarta: Gavamedia.

[8] N. Dunn, William. Introduction to Public Policy Analysis. 2003. Yogyakarta: Gadjah Mada University Press.

[9] Nugroho, Riant, 2017. Public Policy. Jakarta: PT Elex Media Komputindo. 
[10] Putera, Roni Ekha; Heru Nurasa dan Yogi Suprayogi Sugandi. (2016). Synergizing Stakeholders in Reducing Risk of Earthquake and Tsunami-Disaster in the Most Vulnerable Area. International Journal of Administrative Science \& Organization, Vol 23 Number 3.

[11] Putera, Roni Ekha dan Suherlan. (2015). When The Disaster Treatment In The Head Of Eyes: The Efforts Of Mitigation Policy And Reduction Of The Disaster Risk In Padang City. International Refereed Research Journal Vol.-VI, Issue - 4(1).

[12] Winarno, Budi. 2002. Public Policy, Theory and Process. Yogyakarta: Media Presindo

[13] https://en.wikipedia.org/wiki/Geography_Kota_Padang. accessed on May 28, 2018. At: 21:50 hrs

[14] TIM LIPI, 2006, Community Preparedness Study in Anticipating Earthquake and Tsunami Disaster in Indonesia, LIPI-UNESCO / ISDR, Jakarta. [12] www.bukue.lipi.go.id/utama.cgi?lihatarsip\&jans001...1. Retrieved on June 28, 2018.path 00.14

[15] UNISDR, 2012 How To Make Cities More Resilient: A Handbook For Local Government Leaders.

[16] Data KOGAMI Kota Padang, http://www.gitews.org/tsunami-kit/en/E5/info/KOGAMI.pdf. accessed on June 7, 2018

[17] Data BPBD Padang. Presentation Materials Seminar Year 2018

[18] Law Number 24 Year 2007 on Disaster Management and Government Regulation of Padang City

[19] Government Regulation of Padang City Number 3 Year 2008 on Disaster Management 